\title{
"The impact of banking sector development on economic growth: Comparative analysis of Ukraine and some EU countries"
}

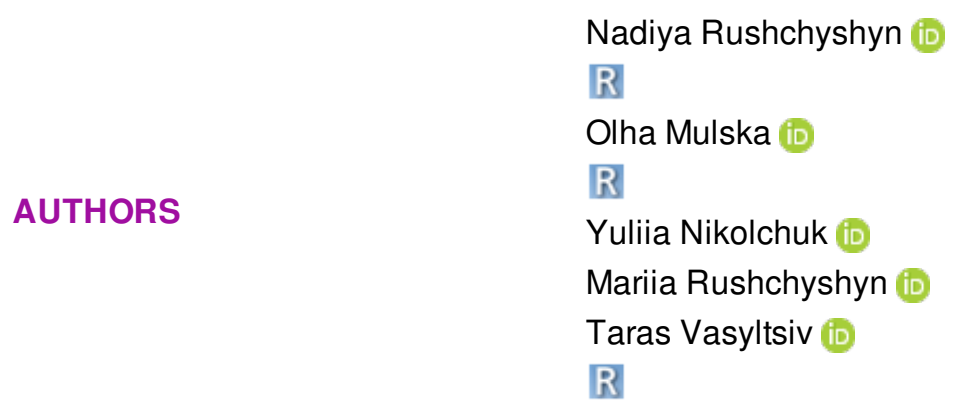

Nadiya Rushchyshyn, Olha Mulska, Yuliia Nikolchuk, Mariia Rushchyshyn and Taras Vasyltsiv (2021). The impact of banking sector development on economic ARTICLE INFO growth: Comparative analysis of Ukraine and some EU countries. Investment Management and Financial Innovations, 18(2), 193-208. doi:10.21511/imfi.18(2).2021.16

DOI $\quad$ http://dx.doi.org/10.21511/imfi.18(2).2021.16

RELEASED ON

Monday, 31 May 2021

RECEIVED ON

Monday, 29 March 2021

ACCEPTED ON

Tuesday, 25 May 2021

\section{$(c)$ EY}

LICENSE

This work is licensed under a Creative Commons Attribution 4.0 International License

JOURNAL

"Investment Management and Financial Innovations"

ISSN PRINT $1810-4967$

ISSN ONLINE $1812-9358$

PUBLISHER

LLC "Consulting Publishing Company "Business Perspectives"

FOUNDER

LLC "Consulting Publishing Company "Business Perspectives"

NUMBER OF REFERENCES

39
NUMBER OF FIGURES

1
NUMBER OF TABLES

8

(C) The author(s) 2021. This publication is an open access article. 


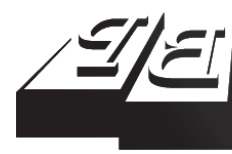

BUSINESS PERSPECTIVES

(2)

LLC "CPC "Business Perspectives" Hryhorii Skovoroda lane, 10, Sumy, 40022, Ukraine www.businessperspectives.org
Received on: $29^{\text {th }}$ of March, 2021 Accepted on: $25^{\text {th }}$ of May, 2021 Published on: $31^{\text {st }}$ of May, 2021

(c) Nadiya Rushchyshyn, Olha Mulska, Yuliia Nikolchuk, Mariia Rushchyshyn, Taras Vasyltsiv, 2021

Nadiya Rushchyshyn, Doctor of Economics, Associate Professor, Department of Financial and Economic Security and Banking Business, Lviv University of Trade and Economics, Ukraine.

Olha Mulska, Ph.D., Senior Research Fellow, Department of Social and Humanitarian Development of the Regions, M. I. Dolishniy Institute of Regional Research of the Nationa Academy of Sciences of Ukraine, Ukraine. (Corresponding author)

Yuliia Nikolchuk, Ph.D., Associate Professor, Head of the Department of Finance, Accounting and Auditing, Khmelnytskyi Cooperative Trade and Economic Institute, Ukraine.

Mariia Rushchyshyn, Postgraduate of the Department of Finance, Money Circulation and Credit, Ivan Franko National University, Ukraine.

Taras Vasyltsiv, Doctor of Economics, Professor, Head of the Department of Social and Humanitarian Development of the Regions, M. I. Dolishniy Institute of Regional Research of the National Academy of Sciences of Ukraine, Ukraine.

This is an Open Access article, distributed under the terms of the Creative Commons Attribution 4.0 International license, which permits unrestricted re-use, distribution, and reproduction in any medium, provided the original work is properly cited.

Conflict of interest statement: Author(s) reported no conflict of interest
Nadiya Rushchyshyn (Ukraine), Olha Mulska (Ukraine), Yuliia Nikolchuk (Ukraine), Mariia Rushchyshyn (Ukraine), Taras Vasyltsiv (Ukraine)

\section{THE IMPACT OF BANKING SECTOR DEVELOPMENT ON ECONOMIC GROWTH: COMPARATIVE ANALYSIS OF UKRAINE AND SOME EU COUNTRIES}

\begin{abstract}
The effective functioning of the banking sector has a key impact on the stability of economic growth. The study is aimed at monitoring the banking sector development and identifying causality between the banking sector and economic growth. The meth odological tools of the research are Principal component analysis, causal relationship, and vector regression modeling. The empirical study is based on the World Bank databank by eight components (for integral analysis) and seven indicators (for causality analysis). The study presents an improved algorithm for monitoring the level of banking sector development based on calculating the integral coefficient. According to assessment, the level of banking sector development and realization of its potential in Ukraine is low and significantly inferior to the EU countries; in 2000-2019, the development of the banking sector in Ukraine was 0.061-0.153. The results obtained confirmed the large discrepancy in the development of Ukraine's banking sector with some EU countries (the highest lag values were observed with the Czech Republic and Poland). The causality analysis revealed a strong favorable relationship between the level of development of the banking sector in Ukraine and GDP per capita (0.796), a moderate one - with foreign direct investment (0.400), and a reverse relationship with the level of national poverty (0.678). This study is of practical value for identifying two possible trajectories of a country's development, namely, sustainable development and economic turbulence, and has allowed forming a conceptual vision of the role of the banking sector in achieving social and economic goals.
\end{abstract}

Keywords

banking sector, indicator, divergence, integral assessment, causality, lag, stability, Ukraine, EU countries

\section{JEL Classification G21, G28, E63}

\section{INTRODUCTION}

High quality and stable functioning of the banking sector as one of the conditions for the effective functioning of a market economy play a key role in social and economic progress. Significant changes affecting the Ukrainian banking sector in recent years are due to external (transformations of international financial markets, globalization processes and widespread financial innovations) and internal (macroeconomic and political instability, worsening of the institutional and managerial capacity of the economic development management system in general and use of the potential of the banking sector for these purposes) factors.

After the financial and economic crisis in 2008-2009, the banking sector of Ukraine has undergone numerous changes. Thus, a significant number of international banks abandoned cross-border banking, initiating the era of retransmission operations. The number of foreign 
banking structures in Ukraine, including subsidiaries, has decreased; there has been a reduction in the volume of cross-border banking operations, and the development of local bank financing. Afterwards, the transformation of the global banking system resulted in the introduction of the banks in Ukraine, which helped to increase their competitiveness and certain aspects of the efficiency of Ukraine's banking sector due to banking control, and avoid a significant rate of non-performing loans.

The socio-economic, financial and political convergence of Ukraine with the European Union, as well as the country's economic growth, depend on the efficiency and effectiveness of its financial system, in particular the banking sector. Commercial banks have to become the centers of the financial system and payments, play a key role in the process of mobilization planning of the economy, identify longterm investment opportunities, insure investment, financial and other business risks. The effective activity of Ukraine's banking sector in a competitive environment, which consists of minimal state intervention, less market concentration and a significant amount of investment and commercial banks, will contribute to the trajectory of sustainable economic development and minimize economic turbulence.

The relationship between the banking sector and economic growth is due to the growth of investment opportunities and the emergence of profitable projects, facilitating the exchange of goods and services, creating a network of payment services, mobilizing and pooling savings of some investors, obtaining and processing information flow about business structures. The priority tasks of the banking sector on the way to establishing social and economic stability are consigning savings for their productive use in investment activities, monitoring the investment and innovation sphere, and diversifying liquid assets. The banking sector, guaranteeing access and controlling a significant part of the active money supply, affects the volume of industrial production and the nature of production factors. By determining the amount of mobilized financial and investment resources, as well as the efficiency of individual segments of the economy, the banking sector is a trigger of social and economic development.

\section{LITERATURE REVIEW AND HYPOTHESIS}

Considering that the methodological framework of this study consists of two consecutive but interconnected blocks, it is based on the generalization of scientific publications, which relate, firstly, to the identification of factors and conditions, methodological approaches to assessing the banking sector development, its impact on social and economic development; secondly, to the methods, directions, tools and means of state policy for the formation and realization of financial instruments for realizing the banking sector's potential in stimulating sustainable development of the country. This required taking into account the research results, substantiating the indicators and methods of analyzing the parameters of the efficiency of the financial system, including its banking sector, especially organizational development (Chanderjeet, 2017), the level of losses (Hashim \& O'Hanlon, 2016), bank liquidity (Munteanu, 2012), social responsibility of the financial and credit system (Revelli \& Viviani, 2015), efficiency and reliability of banking activity (Schaeck \& Čihák, 2008), competitiveness of the banking system (Wahyudi et al., 2021), the profitability of financial sector entities (Yuksel et al., 2018). Assessments made based on the criterion of "compliance with the standards and quality requirements of financial management by the subjects of the banking sector in the country" are endowed with a similar character. Such conclusions can be made based on the international standards of financial and analytical reporting (Casta et al., 2019; Mantzari et al., 2017), reporting on the quality of using financial instruments (Ryan, 2011), social responsibility of financial and credit structures (Burianová \& Paulík, 2014), accounting for financial transactions (Gebhardt et al., 2003) and ensuring financial stability (Novotny-Farkas, 2016).

It is also quite important to consider the financial risk factor, as the growing risk of financial and banking operations objectively impairs the ability of the banking sector to function properly and, consequently, the realization of its potential for economic growth. In this aspect, the research re- 
sults by Amandeep and Garima (2019), Bushman and Williams (2012), Fonseca and Gonzalez (2008), Ruthenberg and Landskroner (2008), and Weber et al. (2015) have high theoretical and applied value. Substantiating the methodology for assessing the impact of the banking sector on the economy, the research on the relationship between the effectiveness of banking structures and social and economic growth is interesting and substantial for scientific discourse (Auster \& Pavoni, 2018; Casu \& Girardone, 2009; Luo, 2015; Naceur et al., 2009; Rajesh et al., 2014; OECD, 2017).

The development of the financial market and the transformation of the banking sector create a need for diagnostics of its financial measures. Yasynska (2021) determined the level of the Ukrainian banking sector financial security in the event of decapitalization of the national economy. Aloqool et al. (2014) tested the causality between banks and the economic growth in Jordan from 1980 to 2012. They examined the correlation between the gross financing and the total savings and growth, deposits and GDP. Liang and Reichert (2006) tested a casual relationship between bank development and economic growth in emerging and developed countries. They used Granger causality and the Odedokun model to derive the results. They argued that the production function of economic growth appears to be more informative. Their model is consistently indicate a strong supplyleading relation between banking sector development and economic output. Moreover, Caporale (2009) examined the relationship between financial development and economic growth in $10 \mathrm{EU}$ countries from 1994 to 2007. They found that stock and money markets are still underdeveloped in these countries and their contribution to economic growth is limited and lack financial debts. Moreover, the result indicates that causality runs from financial development to economic growth, but not in the opposite direction.

Introduction of financial instruments is a joint task: the analysis results of the development and impact of the banking sector on the economy $v s$ the basic regulatory norms and approaches to state regulation of the financial system development and its banking subsystem. Therefore, a number of publications were analyzed, which substantiated the set of regulations and requirements set by state regulators (National Bank) to financial and credit institutions (Flamee \& Windels, 2009; Ilyash et al., 2020; Pushkala et al., 2017; Sivasubramaniam, 2018). It is important to consider current trends, in particular regarding the digitization of financial and economic relations (Gabor \& Brooks, 2017), the development of electronic banking systems (Maurice Ayuketang Nso, 2018), and data management RegTech (Zetzsche et al., 2019) when determining the strategic priorities and means of public policy to influence the banking sector with the further realization of its potential to ensure sustainable development.

In addition, some methods and means of effective financial policy of the state have already been developed, including ensuring sustainable development of the national economy. Some of them (see Sobana, 2014; Storonyanska, 2015; Vasyltsiv \& Cherkasova, 2016) are considered when substantiating the banking sector's potential of current financial instruments in stimulating sustainable development of the country.

In this regard, it is very important to assess the impact of the banking sector development on economic growth and create the conceptual vision of the place and role of the financial system in ensuring strategic sustainable economic development. Based on previous research, the following hypothesis is put forward:

\section{$H_{1}$ : High level of the banking sector development (effective realization of its potential) has a significant impact on the social and econom- ic development of the country.}

\section{METHODS}

The initial stage of assessing the impact of the banking sector on economic development, and, consequently, identifying the relationship between the efficiency of the banking sector and the country's economic growth is to obtain an empirical indicator of the banking sector development. The system of financial instruments most often used by banking institutions determines the development of the banking sector. The methodology for constructing an empirical indicator of the banking sector development involves bringing in- 
dicators to a homogeneous series, calculating the coefficients of weight significance of indicators, determining the weighted coefficients of the banking sector development, and building time series of integral indicators of the banking sector development of individual countries.

The indicators are standardized according to formula (1) for indicators that contribute to the development of the banking sector (the ratio of bank capital and assets, \%; the ratio of liquid bank reserves and assets, \%; the number of branches of commercial banks, per 100,000 people ( $>18$ years); lending to the private sector by commercial banks, \% of GDP; credit information depth index, rank $[0 ; 8]$ ) and, according to formula (2), for those indicators whose growth has a reverse impact on the development of the country's banking sector (the ratio of non-performing bank loans and total gross loans of banks, $\%$; interest rate of commercial banks on the loan, \%; spread of interest rates of banks, \%).

$$
\begin{aligned}
& a_{i t n}^{+}=z_{i t n} / z_{i t n}^{\max }, \\
& a_{i t n}^{-}=z_{i t n} / z_{i t n}^{\min },
\end{aligned}
$$

where $a_{i t n}^{+}$is a standardized $i$-th indicator in $t$ time interval, which contributes to building the potential of the banking sector of $n$-th country; $a_{i t n}^{-}$is a standardized $i$-th indicator in $t$-time interval, which has a reverse impact on the banking sector development of $n$-th country; $z_{i t n}$ is an initial value of $i$-th indicator of $n$-th country in $t$-time interval; $z_{i t n}^{\max }, z_{i t n}^{\min }$, are maximum and minimum values of $i$-th indicators within the set of $n$-th countries in $t$-time interval.

The coefficients of weight significance of indicators of the banking sector development are calculated using the Principal component analysis (formula 3); its choice is due to the presence of numerous variables with different units of measurement. According to the main component method, the process of weighing indicators is carried out simultaneously on the parameters of time and space, which allows identifying the relational structure between the indicators.

$$
w_{i n}=\frac{\left|\operatorname{comp}_{i}^{n}\right|}{\sum_{i=1}^{j}\left|c o m p_{i}^{n}\right|},
$$

where $w_{i n}$ is the weight of $i$-th indicator of $n$-th country; comp ${ }_{i}^{n}$ is the main component of $i$-th indicator of $n$-th country; and $j$ is the number of indicators.

Weighted coefficients of indicators (formula 4) and integral indicators (formula 5) of the banking sector development of individual countries are calculated using a multiplicative approach.

$$
\begin{aligned}
& W C I_{i t}^{n}=\prod_{i=1}^{j} a_{i t n}^{w_{i n}}, \\
& \operatorname{InBD}_{t}^{n}=\prod_{i=1}^{j} W C I_{i t}^{n},
\end{aligned}
$$

where $W C I_{i t}{ }^{n}$ is a weighted coefficient of $i$-th indicator of the banking sector development of $n$-th country in $t$-time interval; $w_{k}$ is a coefficient of weight significance of $k$-th group of indicators; $\operatorname{InBD} D_{t}^{n}$ is an integral indicator of the banking sector development of $n$-th country in t-time interval.

To confirm a thesis of the existence of a significant favorable impact of the banking sector on the country's social and economic development, an econometric study was carried out based on three stages: establishing the strength of the relationship between the parameters of social and economic development of the country and the level of the banking sector development; identifying causality between the level of the banking sector development and the parameters of social and economic development of countries; and determining the impact of the banking sector on the country's social and economic development.

To construct a series of dynamics of empirical indicators of the studied countries' social and economic development, the method based on the implementation of the algorithm for calculating the integral coefficients of the banking sector development was used. To identify the impact of the banking sector on the social and economic development of the country, a vector regression model was created, in which the vector of exogenous variables $Y_{t}$ is the parameters of social and economic development of the EU and Ukraine, and endogenous variables $X_{t}$ are integral indicators of the banking sector development in 2000-2019.

For analysis, the choice has been made among some EU countries with which Ukraine has cross-bor- 
der cooperation (Poland, Hungary, and Romania), as well as countries with high GDP per capita (the Czech Republic) and the share of the banking sector in GDP of the country (Switzerland).

\section{RESULTS}

By standardizing the indicators, the weight significance of each indicator of the banking sector development for the EU and Ukraine was calculated (Table 1). It should be emphasized that the indicators of "private sector lending by banks", "the ratio of bank capital to assets" and "credit information depth index" have the highest levels of importance. Thus, for the Czech Republic and Poland, these figures were $16.48 \%$ and $19.13 \%, 17.02 \%$ and $3.69 \%$, $16.37 \%$ and $19.78 \%$, respectively. Ukraine is characterized by the highest weight significance of the private sector lending indicator by banks (20.69\%) among the studied countries and the lowest value of the indicator of the credit information depth index (1.13\%). Empirical assessments indicate the high economic importance of business lending by commercial banks in Ukraine, but at the same time, they show the unformed credit market and the lack of information platforms for commercial crediting.

Poland and the Czech Republic have the lowest values of weight coefficients for the ratio of liquid reserves to bank assets $3.43 \%$ and $6.44 \%$, respectively). Switzerland is the leading country in terms of the number of branches of commercial banks, therefore, the weight significance of this indicator is high (15.36\%). The results of the calculations confirmed the thesis that in Ukraine this indicator is not an important component of the banking sector development, as the weight ratio is $3.37 \%$, and it is the lowest one among the studied EU countries. In contrast, Ukraine has the highest weight significance of the "spread of bank interest rates" indicator (18.36\%) among the surveyed countries, and the lowest weight is in Switzerland (5.87\%). In particular, for Romania and Hungary, this indicator has the highest weight significance (16.35\% and 16.68\%) among all indicators of the banking sector development.

Weighted indices of indicators of the banking sector development of the EU and Ukraine (Appendix A), calculated using normalized values of indicators and their weights, show the trends of its development for each indicator in particular. Thus, in 2000, the highest level of development of the Czech banking sector was characterized by the number of branches of commercial banks (0.956) and the credit information depth index (0.954), the lowest value was observed by the indicator of lending to the private sector by banks (0.787). The highest values of Polish indices in 2019 could be traced by indicators of the credit information depth (1.00), the ratio of bank capital and assets (0.983), and liquid reserves and assets of commercial banks (0.955). In 2000-2019, in the Czech Republic and Switzerland, there were high rates of the banking sector development by all indicators, except for the number of branches of commercial banks. It is noteworthy that in Poland and Romania, the regressive development of the bank-

Table 1. Weight coefficients of indicators of banking sector development indices in some EU countries, Switzerland, and Ukraine, \%

Source: Authors' calculations based on the World Bank databank using Statistica 7 software and formula (3).

\begin{tabular}{|c|c|c|c|c|c|c|}
\hline \multirow[b]{2}{*}{ Indicators } & \multicolumn{6}{|c|}{ Countries } \\
\hline & $\begin{array}{l}\text { Czech } \\
\text { Republic }\end{array}$ & Poland & Romania & Hungary & Ukraine & Switzerland \\
\hline The ratio of bank capital and assets, $\%$ & 17.02 & 3.69 & 10.38 & 11.07 & 8.76 & 13.43 \\
\hline The ratio of liquid bank reserves and assets, $\%$ & 6.44 & 3.43 & 15.59 & 13.28 & 17.83 & 9.93 \\
\hline $\begin{array}{l}\text { The ratio of non-performing bank loans and total } \\
\text { gross loans of banks, } \%\end{array}$ & 12.11 & 2.56 & 5.35 & 15.78 & 13.33 & 14.38 \\
\hline $\begin{array}{l}\text { Number of branches of commercial banks, per } \\
100,000 \text { adults }\end{array}$ & 4.35 & 15.49 & 9.87 & 6.52 & 3.37 & 15.36 \\
\hline Lending to the private sector by banks, $\%$ of GDP & 16.48 & 19.13 & 11.81 & 9.74 & 20.69 & 15.28 \\
\hline Interest rate of banks on the loan, \% & 14.67 & 18.16 & 15.79 & 15.66 & 16.53 & 12.53 \\
\hline Spread of interest rates of banks, $\%$ & 12.56 & 17.75 & 16.35 & 16.68 & 18.36 & 5.87 \\
\hline Credit information depth index, rank & 16.37 & 19.78 & 14.86 & 11.29 & 1.13 & 13.23 \\
\hline
\end{tabular}


ing sector is monitored by indicators of the ratio of bank capital and assets, liquid reserves and assets, bank non-performing credits and gross loans.

In 2019, Ukraine had the lowest values of the weight coefficient in terms of the ratio of non-performing credits and gross loans (0.561). For comparison, Switzerland had the value of 0.999 , Hungary had 0.873 , and Romania had 0.906 . The highest values of indices in Ukraine were in terms of the ratio of bank capital to assets (0.991 in 2019 and 0.986 in 2001). The decline in the banking sector development in Ukraine in 2000-2019 is monitored by the number of branches of commercial banks. Thus, Ukraine's lag in the level of the banking sector development from neighboring countries is growing, and there is a significant divergence with the Czech Republic and Switzerland.

Weight coefficients and weighted indices of indicators served as the necessary criteria for constructing the time series of integral indices of the banking sector development of Ukraine and the EU countries during 2000-2019 (Table 2).

The results obtained confirmed the thesis about the high importance of Ukraine's divergence with the EU countries in terms of the level of the banking sector development. In particular, the highest lag values were observed with the Czech Republic, Poland and Switzerland, while the moderate ones were with Romania and Hungary. Thus, 2008 and 2010 are considered the peak periods of the development of Ukraine's banking sector. With the beginning of the annexation of Crimea and hostilities in Luhansk and Donetsk regions, Ukraine's economic system underwent destructive changes, the stability of social and economic and financial systems was disrupted, which weakened the competitiveness of the economy and slowed the banking sector development. In 2019, the integral index was 0.108 , which was $12.9 \%$ and $29.4 \%$ less than in 2014 and 2008, respectively.

According to the results of a comprehensive correlation analysis (Table 3), it is established that in Ukraine a strong favorable relationship (on the Chaddock scale) is observed between the level of the banking sector development and GDP per capita (a correlation coefficient is equal to 0.796), a moderate one is foreign direct investment (0.400), and a reverse relationship is the level of national poverty (a correlation coefficient is -0.678). The inverse relationship can be explained by the fact

Table 2. Integral coefficients of the banking sector development of some EU countries, Switzerland, and Ukraine, 2000-2019

Source: Authors' calculations based on data from Table 1, Appendix A, and formulas (4) and (5).

\begin{tabular}{|c|c|c|c|c|c|c|}
\hline \multirow{2}{*}{ Period } & \multicolumn{6}{|c|}{ Countries } \\
\hline & Czech Republic & Poland & Romania & Hungary & Ukraine & Switzerland \\
\hline 2000 & 0.29162 & 0.24154 & 0.17102 & 0.24098 & 0.06133 & 0.61325 \\
\hline 2001 & 0.28033 & 0.23221 & 0.18322 & 0.24591 & 0.07321 & 0.57871 \\
\hline 2002 & 0.27492 & 0.21969 & 0.19468 & 0.25659 & 0.07853 & 0.60322 \\
\hline 2003 & 0.28409 & 0.27178 & 0.20442 & 0.24571 & 0.10020 & 0.61470 \\
\hline 2004 & 0.28246 & 0.29468 & 0.21439 & 0.24681 & 0.10713 & 0.59864 \\
\hline 2005 & 0.28934 & 0.30176 & 0.23399 & 0.20368 & 0.11352 & 0.58322 \\
\hline 2006 & 0.29696 & 0.33456 & 0.25535 & 0.27779 & 0.11012 & 0.60743 \\
\hline 2007 & 0.29681 & 0.36067 & 0.29835 & 0.28005 & 0.12378 & 0.60170 \\
\hline 2008 & 0.30295 & 0.39452 & 0.29854 & 0.28092 & 0.15333 & 0.57266 \\
\hline 2009 & 0.29868 & 0.40384 & 0.26452 & 0.24137 & 0.13031 & 0.58249 \\
\hline 2010 & 0.29776 & 0.40805 & 0.25481 & 0.25101 & 0.14296 & 0.59596 \\
\hline 2011 & 0.30244 & 0.41264 & 0.25957 & 0.23531 & 0.12686 & 0.60075 \\
\hline 2012 & 0.31089 & 0.41809 & 0.25751 & 0.22848 & 0.12696 & 0.59421 \\
\hline 2013 & 0.33184 & 0.41962 & 0.25761 & 0.25122 & 0.13944 & 0.63230 \\
\hline 2014 & 0.33308 & 0.41912 & 0.26755 & 0.26236 & 0.12413 & 0.64526 \\
\hline 2015 & 0.34603 & 0.41811 & 0.28280 & 0.30331 & 0.10864 & 0.65535 \\
\hline 2016 & 0.36720 & 0.41970 & 0.29585 & 0.32085 & 0.10873 & 0.67419 \\
\hline 2017 & 0.38916 & 0.41630 & 0.30110 & 0.37257 & 0.10113 & 0.73584 \\
\hline 2018 & 0.39901 & 0.41688 & 0.27570 & 0.39048 & 0.09518 & 0.72996 \\
\hline 2019 & 0.40515 & 0.41291 & 0.27695 & 0.42829 & 0.10755 & 0.73462 \\
\hline
\end{tabular}


Table 3. The strength of the link between the level of the banking sector development and the parameters of social and economic development in some EU countries, Switzerland, and Ukraine, 2000-2019.

Source: Authors' own compilation.

\begin{tabular}{|c|c|c|c|c|c|c|c|c|}
\hline \multirow{2}{*}{ Countries } & \multirow{2}{*}{ Indicators } & \multicolumn{7}{|c|}{$\operatorname{InBD}^{n}-S^{\prime} D_{i}^{n}$} \\
\hline & & $\ln B D_{t}^{n}-X_{1}$ & $\ln B D_{t}^{n}-X_{2}$ & $\ln B D_{t}^{n}-X_{3}$ & $\ln B D_{t}^{n}-X_{4}$ & $\ln B D_{t}^{n}-X_{5}$ & $\ln B D_{t}^{n}-X_{6}$ & $\ln B D_{t}^{n}-X_{t}$ \\
\hline \multirow{3}{*}{$\begin{array}{l}\text { Czech } \\
\text { Republic }\end{array}$} & $r$ & $0.6429 * * *$ & $-0.3740 *$ & $-0.8709 * * *$ & $-0.6073^{* * *}$ & $0.7673^{* * *}$ & $0.5746 * * *$ & 0.1462 \\
\hline & $R^{2}$ & 0.4133 & 0.1399 & 0.7584 & 0.3689 & 0.5887 & 0.3302 & 0.0214 \\
\hline & $t$-test & 3.5610 & -1.7110 & -7.5165 & -3.2435 & 5.0758 & 2.9785 & 0.6270 \\
\hline \multirow{3}{*}{ Poland } & $r$ & $0.9602 * * *$ & -0.2641 & $0.7952 * * *$ & $0.7007^{* * *}$ & $0.8344 * * *$ & $0.7052 * * *$ & $-0.7997 * * *$ \\
\hline & $R^{2}$ & 0.9219 & 0.0698 & 0.6324 & 0.4910 & 0.6962 & 0.4974 & 0.6394 \\
\hline & $t$-test & 14.5782 & -1.1618 & 5.5648 & 4.1667 & 6.4221 & 4.2204 & -5.6500 \\
\hline \multirow{3}{*}{ Ukraine } & $r$ & $0.7959 * * *$ & $0.4004 * *$ & 0.1285 & -0.3049 & 0.3232 & 0.1789 & $-0.6781^{* * *}$ \\
\hline & $R^{2}$ & 0.6334 & 0.1603 & 0.0165 & 0.0929 & 0.1044 & 0.0320 & 0.4598 \\
\hline & $t$-test & 5.5773 & 1.8536 & 0.5497 & -1.3581 & 1.4489 & 0.7715 & -3.9146 \\
\hline \multirow{3}{*}{ Switzerland } & $r$ & $0.4786^{* *}$ & -0.0006 & $-0.5620^{*}$ & $-0.6661^{* *}$ & $-0.6569 * *$ & $0.8308^{* * *}$ & 0.1023 \\
\hline & $R^{2}$ & 0.2291 & 0.0000 & 0.3158 & 0.4436 & 0.4316 & 0.6903 & 0.0105 \\
\hline & $t$-test & 2.3127 & -0.0027 & -2.8824 & -3.7885 & -3.6969 & 6.3335 & 0.4364 \\
\hline \multirow{3}{*}{ Romania } & $r$ & $0.8954 * * *$ & 0.0040 & -0.2075 & 0.0074 & $0.4725^{*}$ & $0.7111^{* *}$ & $-0.8562 * * *$ \\
\hline & $R^{2}$ & 0.8018 & 0.0000 & 0.0430 & 0.0001 & 0.2233 & 0.5056 & 0.7330 \\
\hline & $t$-test & 8.5329 & 0.0170 & -0.8997 & 0.0315 & 2.2747 & 4.2908 & -7.0299 \\
\hline \multirow{3}{*}{ Hungary } & $r$ & $0.5396 * *$ & -0.1200 & $-0.8736^{* * *}$ & $-0.4112^{*}$ & $-0.6774 * *$ & $0.5674 * *$ & $-0.5982 * * *$ \\
\hline & $R^{2}$ & 0.2912 & 0.0144 & 0.7632 & 0.1691 & 0.4588 & 0.3220 & 0.3578 \\
\hline & $t$-test & 2.7195 & -0.5128 & -7.6163 & -1.9137 & -3.9066 & 2.9236 & -3.1668 \\
\hline
\end{tabular}

Note: $r$ is a correlation coefficient; $R^{2}$ is a coefficient of determination; t-test is Student's criterion; ***,**, and * are significant at the level of $1 \%, 5 \%$, and $10 \%$, respectively; $S E D_{i}^{n}$ is a system of $i$-th parameters of social and economic development of $n$-th country ( $\mathrm{X}_{1}$ is a GDP per capita, USD; $\mathrm{X}_{2}$ is a share of foreign direct investment, \% of GDP; $\mathrm{X}_{3}$ is an employment level, $\%$ (ILO methodology); $X$ is a share of gross value added of industry (including construction), \% of GDP; $X_{5}$ is a share of high technology exports, $\%$ of total exports; $X_{6}$ is a share of alternative energy sources, $\%$ of total energy consumption; $X_{7}$ is a level of national poverty (World Bank methodology), \% of the total population; $\ln B D_{t}{ }^{n}$ is an integral indicator of the banking sector development of $n$-th country.

that in Ukraine the middle class is significantly depressed due to the lack of favorable conditions for its formation and development environment, so the growing gap between the rich and poor without appropriate policies to create new jobs and provide high-paying workplaces, as well as to create favorable conditions for self-employment and doing business will exacerbate poverty in Ukraine. This trend is observed in Hungary and Romania. In the Czech Republic and Switzerland, the link between the level of the banking sector development and the share of the poor is weak.

Effective realization of the banking sector's potential plays a key role in forming the vector of Ukraine's sustainable development. The growth of bank capital and the formation of the credit market accelerates economic growth, helps reduce the shadowing of the economy and avoid tax evasion by businesses, in particular through the use of offshore jurisdictions. Empirical assessments of the causality of the banking sector development and the parameters of social and economic develop- ment of the EU and Ukraine showed the existence of a causal relationship between the studied variables, which is characteristic for each country, in particular within the economic system, respectively (Table 4). Thus, with a one-year lag (shortterm period), the banking sector in the Czech Republic causes GDP growth per capita. The casual impact of the country's banking sector on the gross value added of industry and the export of high technology is observed in two-time lags. Instead, the Polish banking sector is a regressor of growth in the share of gross value added of the industry and high-tech exports only in the short term. The impact of commercial banks on GDP and foreign direct investment is observed with a lag of three years. It should be noted that Poland is characterized by a significant casual connection between the share of the use of alternative energy sources in energy consumption and the banking sector in two lags at the same time.

A distinctive feature of Ukraine's economy is the dependence of industrial product sales on the 
Table 4. Mutual causality of parameters of economic growth and the banking sector development of some EU countries, 2000-2019

\begin{tabular}{|c|c|c|c|c|c|c|c|c|}
\hline \multirow{3}{*}{ Variables } & \multicolumn{2}{|c|}{ Czech Republic } & \multicolumn{2}{|c|}{ Poland } & \multicolumn{2}{|c|}{ Romania } & \multicolumn{2}{|c|}{ Hungary } \\
\hline & \multicolumn{8}{|c|}{ Lags } \\
\hline & 1 & 3 & 1 & 3 & 1 & 3 & 1 & 3 \\
\hline \multirow{2}{*}{$\operatorname{lnBD}_{t}^{n} \rightarrow X_{1}$} & 3.38 & \multirow{2}{*}{-} & \multirow{2}{*}{ - } & 3.05 & 3.00 & \multirow{2}{*}{ - } & \multirow{2}{*}{-} & 2.88 \\
\hline & $(0.08 *)$ & & & $(0.09 *)$ & $(0.09 *)$ & & & $(0.10 *)$ \\
\hline \multirow{2}{*}{$\operatorname{lnBD}_{t}^{n} \rightarrow X_{2}$} & \multirow{2}{*}{ - } & \multirow{2}{*}{-} & \multirow{2}{*}{-} & 2.75 & \multirow{2}{*}{ - } & 5.22 & \multirow{2}{*}{-} & \multirow{2}{*}{-} \\
\hline & & & & $(0.09 *)$ & & $(0.02 * *)$ & & \\
\hline \multirow{2}{*}{$\operatorname{lnBD}_{t}^{n} \rightarrow X_{3}$} & \multirow{2}{*}{-} & \multirow{2}{*}{-} & \multirow{2}{*}{-} & \multirow{2}{*}{-} & 8.08 & 6.36 & 6.69 & 2.87 \\
\hline & & & & & $\left(0.01^{* *}\right)$ & $(0.02 * *)$ & $\left(0.00^{* * *}\right)$ & $\left(0.10^{*}\right)$ \\
\hline \multirow{2}{*}{$\operatorname{lnBD}_{t}^{n} \rightarrow X_{4}$} & 4.20 & 4.55 & 9.04 & \multirow{2}{*}{ - } & \multirow{2}{*}{-} & 3.93 & 4.13 & 3.38 \\
\hline & $\left(0.06^{*}\right)$ & $\left(0.04^{* *}\right)$ & $\left(0.00^{* * *}\right)$ & & & $\left(0.05^{*}\right)$ & $(0.06 *)$ & $\left(0.08^{*}\right)$ \\
\hline \multirow{2}{*}{$\operatorname{lnBD}_{t}^{n} \rightarrow X_{5}$} & 3.74 & 4.23 & 8.63 & \multirow{2}{*}{ - } & 9.25 & 3.85 & 4.03 & \multirow{2}{*}{-} \\
\hline & $(0.07 *)$ & $(0.05 *)$ & $\left(0.00^{* * *}\right)$ & & $\left(0.00^{* *}\right)$ & $(0.05 *)$ & $(0.06 *)$ & \\
\hline \multirow{2}{*}{${\ln B D_{t}^{n}}^{n} \rightarrow X_{6}$} & \multirow{2}{*}{-} & \multirow{2}{*}{-} & 17.68 & 3.47 & 11.22 & \multirow{2}{*}{-} & \multirow{2}{*}{-} & \multirow{2}{*}{-} \\
\hline & & & $\left(0.00^{* * *}\right)$ & $(0.07 *)$ & $\left(0.00^{* * *}\right)$ & & & \\
\hline \multirow{2}{*}{$\operatorname{lnBD}_{t}^{n} \rightarrow x_{7}$} & - & - & 3.63 & - & 3.56 & _- & 5.41 & _- \\
\hline & - & - & $(0.07 *)$ & - & $(0.07 *)$ & - & $\left(0.03^{* *}\right)$ & - \\
\hline
\end{tabular}

Note: The arrow indicates one-sided causality. ${ }^{* * *},{ }^{* *}$, and $*$ are errors at the level of $1 \%, 5 \%$ and $10 \%$, respectively.

level of creditworthiness of commercial banks, which is confirmed by the results of the Granger test (Table 5). It should be distinguished that the banking sector has the potential to increase the share of gross value added of the industry (including construction) and the consumption of alternative energy sources in the short term using credit instruments, as well as GDP growth per capita. In the medium term (lag 4), the banking sector has a dominant influence on for- eign direct investment and poverty. The causal relationship between employment levels and the banking sector development in Ukraine is observed at the level of $95 \%$ of statistical significance with a lag of 6 years, which can be considered as a feature of stable casualness.

According to empirical assessments, Ukraine has no influence of the banking sector on the level of high-tech exports, as the intellectual

Table 5. Mutual causality of parameters of economic growth and the banking sector development of Ukraine and Switzerland, 2000-2019

\begin{tabular}{|c|c|c|c|c|c|c|}
\hline \multirow{3}{*}{ Variables } & \multicolumn{3}{|c|}{ Ukraine } & \multicolumn{3}{|c|}{ Switzerland } \\
\hline & \multicolumn{6}{|c|}{ Lags } \\
\hline & 1 & 4 & 6 & 1 & 4 & 6 \\
\hline \multirow{2}{*}{$\operatorname{lnBD}_{t}^{n} \rightarrow X_{1}$} & 2.57 & \multirow{2}{*}{-} & 2.57 & \multirow{2}{*}{-} & 25.86 & 90.82 \\
\hline & $\left(0.10^{*}\right)$ & & $\left(0.10^{*}\right)$ & & $(0.00 * * *)$ & $\left(0.08^{*}\right)$ \\
\hline \multirow{2}{*}{$\operatorname{lnBD}_{t}^{n} \rightarrow x_{2}$} & \multirow{2}{*}{-} & 2.92 & \multirow{2}{*}{-} & 5.56 & \multirow{2}{*}{-} & 25.86 \\
\hline & & $\left(0.08^{*}\right)$ & & $\left(0.03^{* *}\right)$ & & $(0.00 * * *)$ \\
\hline \multirow{2}{*}{$\operatorname{lnBD}_{t}^{n} \rightarrow X_{3}$} & \multirow{2}{*}{-} & \multirow{2}{*}{-} & 4.03 & 2.53 & \multirow{2}{*}{-} & \multirow{2}{*}{-} \\
\hline & & & $\left(0.2^{* *}\right)$ & $(0.00 * * *)$ & & \\
\hline \multirow{2}{*}{$\operatorname{lnBD}_{t}^{n} \rightarrow X_{4}$} & 2.76 & 5.09 & \multirow{2}{*}{-} & \multirow{2}{*}{-} & \multirow{2}{*}{-} & \multirow{2}{*}{-} \\
\hline & $\left(0.10^{*}\right)$ & $\left(0.03^{* *}\right)$ & & & & \\
\hline \multirow{2}{*}{$\operatorname{lnBD}_{t}^{n} \rightarrow X_{5}$} & \multirow{2}{*}{-} & \multirow{2}{*}{-} & \multirow{2}{*}{-} & 8.23 & \multirow{2}{*}{-} & 92.39 \\
\hline & & & & $\left(0.01^{* *}\right)$ & & $\left(0.08^{*}\right)$ \\
\hline \multirow{2}{*}{$\operatorname{lnBD}_{t}^{n} \rightarrow X_{6}$} & 3.05 & & 121.84 & 8.92 & 17.08 & \multirow{2}{*}{-} \\
\hline & $(0.09 *)$ & & $(0.07 *)$ & $(0.00 * * *)$ & $(0.00 * * *)$ & \\
\hline \multirow{2}{*}{$\operatorname{lnBD}_{t}^{n} \rightarrow X_{7}$} & \multirow{2}{*}{-} & 4.57 & \multirow{2}{*}{-} & \multirow{2}{*}{-} & \multirow{2}{*}{-} & \multirow{2}{*}{-} \\
\hline & & $\left(0.04^{* *}\right)$ & & & & \\
\hline
\end{tabular}

Note: The arrow indicates one-sided causality. ${ }^{* *},{ }^{* *}$, and $*$ are errors at the level of $1 \%, 5 \%$ and $10 \%$, respectively. 
Table 6. Empirical assessments of the impact of the banking sector on the social and economic development of some EU countries, Switzerland, and Ukraine

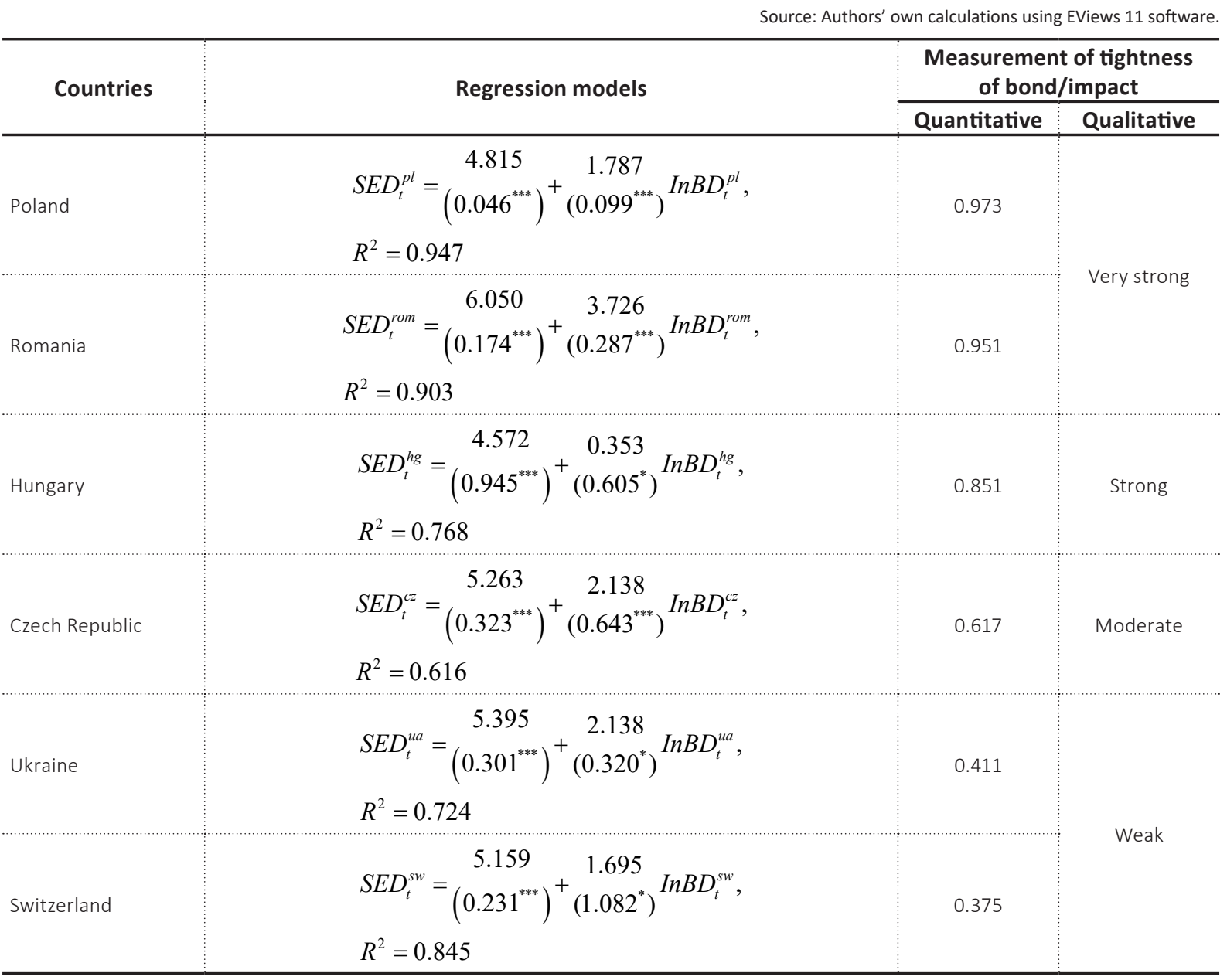

Note: $* * *, * *, *$ are errors at $1 \%, 5 \%$ and $10 \%$, respectively.

property market is not formed, the level of commercialization of scientific developments is low, and commercial banks do not act as financial intermediaries in the innovation sphere. For comparison, in Switzerland, such a systemic relationship is present in the short and long term.

The impact of the banking sector on the social and economic development of the Czech Republic and Poland is favorable at the level of $99 \%$ of statistical significance, determined by $61.6 \%$ and $94.7 \%$, respectively, only by the studied factors (Table 6). It is remarkable that the growth of creditworthiness of commercial banks in the Czech Republic and Poland leads to an increase in production capacity in the industry, strengthening of macroeconomic stability and economic growth by $2.14 \%$ and $1.79 \%$, respectively.
The results of the significance and reliability of economic and mathematical models are within acceptable limits and confirm the adequacy of the conclusions given in Table 7 .

The social and economic system of Ukraine looks rather inertial, since $72.4 \%$ of social and economic development depends on the banking sector, its impact is determined at the level of $90 \%$ of statistical significance. An increase in lending to commercial banks and a rise of the credit information depth index by $1 \%$ will help improve economic stability by $2.14 \%$. Empirical assessments show a favorable impact of the banking sector on Ukraine's economic growth, but the vector of social and economic development is undergoing significant disastrous transformations. Therefore, the pace of development 
Table 7. Indicators of the significance of econometric research (vector regression modeling) of the banking sector's impact on the socio-economic development of some EU countries, Switzerland, and Ukraine

\begin{tabular}{|c|c|c|c|c|c|c|}
\hline \multirow[b]{2}{*}{ Indicators } & \multicolumn{6}{|c|}{ Variables } \\
\hline & $S E D_{t}^{c z}$ & $S E D_{t}^{p l}$ & $S E D_{t}^{u a}$ & $S E D_{t}^{s w}$ & $S E D_{t}^{\text {rom }}$ & $S E D_{t}^{h g}$ \\
\hline Adjusted coefficient of determination & 0.34567 & 0.9445 & 0.70832 & 0.783347 & 0.8984 & 0.699624 \\
\hline Fisher F-test & 11.03756 & 324.3477 & 44.71218 & 2.454810 & 169.0533 & 2.438414 \\
\hline p-level & 0.00379 & 0.0000 & 0.00000 & 0.108015 & 0.0000 & 0.104369 \\
\hline Standard estimation error & 0.14936 & 0.0425 & 0.13830 & 0.120674 & 0.0918 & 0.167717 \\
\hline Student's T-test & 3.32228 & 18.0097 & 6.68672 & 1.56678 & 13.00205 & 1.56154 \\
\hline DW statistics & 2.15 & 1.67 & 2.45 & 2.16 & 1.71 & 2.05 \\
\hline
\end{tabular}

Note: $S E D_{t}^{c z}, S E D_{t}^{p l}, S E D_{t}^{u a}, S E D_{t}^{s w}, S E D_{t}^{r o m}, S E D_{t}^{h g}$ are socio-economic development of the Czech Republic, Poland, Ukraine, Switzerland, Romania, Hungary, respectively.

(1\%) of Ukraine's economic system depends on other factors by $5.4 \%$.

For comparison, the economic growth in Switzerland depends on $84.5 \%$ of the banking sector development, but its impact on social and economic development is weak. Instead, for Romania and Poland, there is a very strong influence of the banking sector on social and economic development (the correlation coefficients are 0.951 and 0.973 , respectively), which indicates a favorable impact of banking potential to ensure economic growth. The results of an empirical assessment of the strength of the banking sector's impact on Ukraine's socio-economic development (0.411) show that the trajectory of Ukraine's economic growth is shifting towards economic turbulence.

Summing up the results, it is noted that the social and economic development of the country will contribute to the stability of the banking sector, increasing credit potential (it is important to avoid accelerating inflation) and reducing government spending. The main task of the banking sector compliance sustainable development is to optimize the distribution of deficit capital, lending to high-tech industries with a high share of value added, ensuring the planned level of consumption by the population or other market participants through savings and borrowing, and the formation of a competitive credit market and the financial intermediation market. Ukraine's banking sector can use appropriate instruments to keep the liquidity of the economy at a high level, finance illiquid assets with liquid liabilities, and minimize liquidity risks and long-term investments.

\section{DISCUSSION}

The key role of the financial system is to ensure sustainable development of the national economy, in particular in the field of small business, forming an efficient credit and capital market, providing financial support, promoting smart infrastructure, implementing monetary policy and regulating the flow of national income. An effective financial system, creating a favorable business environment, helps to reduce poverty and, accordingly, increase living standards, minimize social and economic turbulences, and maximize financial stability (Figure 1).

Realization of the banking sector's potential contributes to strengthening the potential positive investment effects by expanding a network of financial institutions. At the microeconomic level, financial inclusion will contribute to the development of small and medium-sized businesses, increase household consumption of durable goods, which, in turn, will increase living standards and reduce financial deprivation. The banking sector should become a powerful tool of public policy in overcoming the shadow economy, the level of which may increase with the development and spread of new business models and ways to avoid paying taxes (offshoring, tax havens, concealment of profits with individual entrepreneur).

While supporting the program of structural reforms, Ukraine should develop a policy aimed at overcoming financial and economic imbalances and improving the efficiency of resource allocation between strategic sectors of the economy. The main vector of the program should be the formation of a lending strategy on concessional terms 


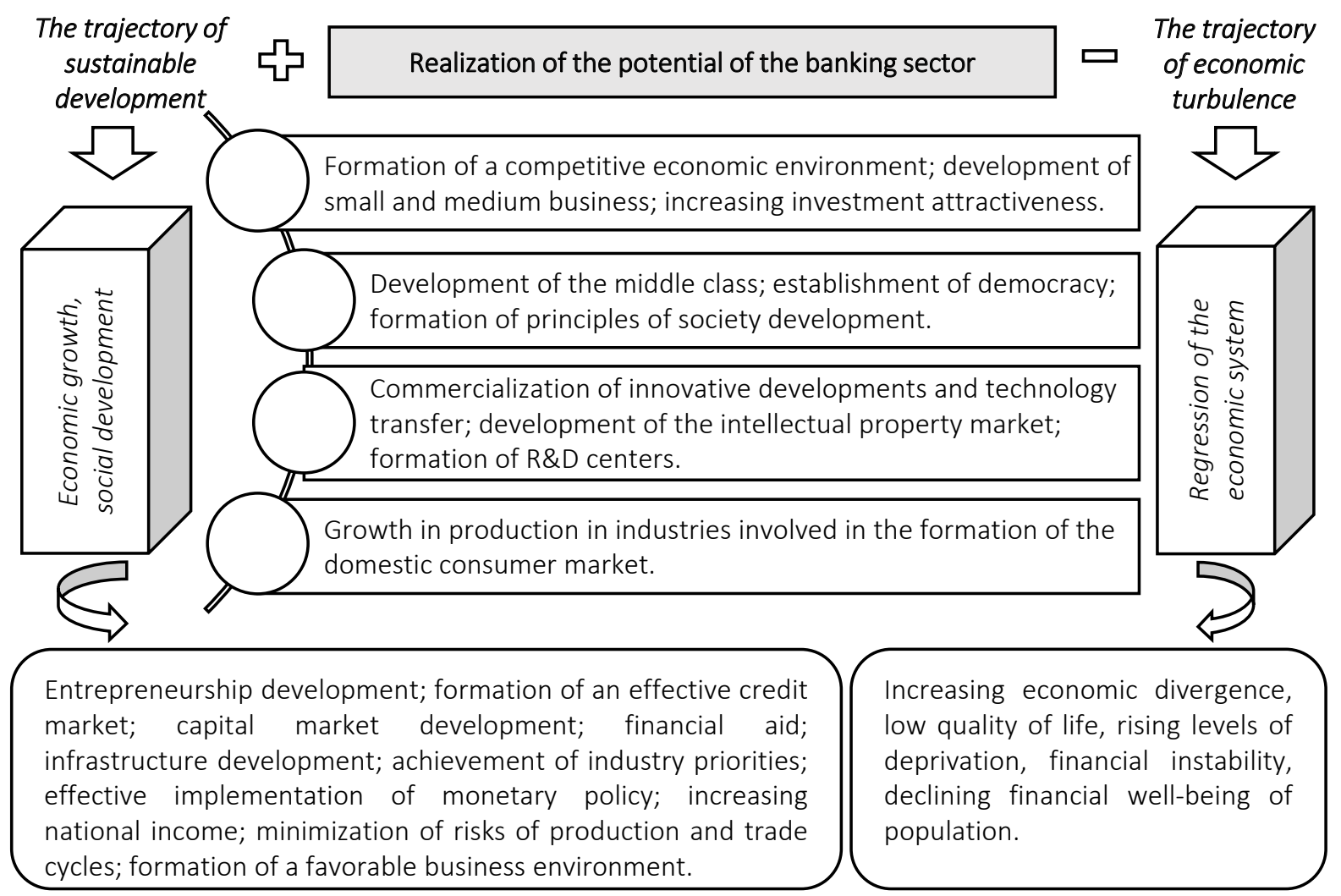

Figure 1. Conceptual vision of the banking sector's place and role in ensuring strategic sustainable economic development

of spinning organizations, obtaining guaranteed loans by R\&D centers and "credit holidays" for organizations that commercialize scientific research. The support of financial sectoral assistance can have an additional positive impact on the implementation of structural reforms and the development of highly productive sectors of the economy.

It should be stressed that the effective implementation of banking sector measures would help to reduce fraud and tax evasion. Ukraine will increase revenues to the state budget, implement fiscal restructuring of the economic system, which will allow achieving sustainable development in the long run. To overcome modern corruption schemes and approaches to money laundering from Ukraine, it is necessary to review the existing tax base, in particular to develop a system for monitoring the impact of any changes in the tax system on certain macroeconomic indicators, ensure an access to credit market for small businesses, spinning organizations and various start-ups, as well as to introduce modern banking innovations.
The development of a state program with the participation of banking institutions to counter transfer pricing will avoid the spread of price manipulation of goods and services on transactions carried out by residents of different countries that are economically interconnected. The development of tools for imposing severe sanctions (fines, freezing, seizure and confiscation of property, revocation of licenses) against participants who carry out money laundering, limited access to banking services for institutions that use fraudulent or illegal methods of raising capital, as well as the development of a system of fines and restrictions on systematic transactions between affiliates and large enterprises are effective means of realizing the banking potential to overcome unfair competition, market monopoly and other problems related to illegal or fraudulent activities.

An effective government policy for realizing the potential of the banking sector in ensuring economic growth in Ukraine, especially in counteracting hidden capital outflows and fraud, creates 
a favorable environment for market competition and maximizes the economic effects of the accumulation of money generated by business activities in Ukraine. The implementation of policy mechanisms will solve the problem of using trans- fer pricing and tax havens. The implementation of economic, tax and regulatory instruments will help reduce transaction costs associated with the use of hidden capital channels, and restrain such processes at the planning stage.

\section{CONCLUSION}

The transformation of the global banking system led to the introduction of domestic banks in local markets, which helped increase their competitiveness and certain aspects of the efficiency of Ukraine's banking sector, the effectiveness of financial market regulation through banking control, and avoid a significant share of non-performing loans. The paper calculates the indicators of the banking sector development in Ukraine and individual EU countries based on the analysis of standardized indicators. The results show the level of banking sector development of Ukraine and EU countries from 2000 to 2019 using principal components analysis. The constructed time series of integral indices proved the high importance of Ukraine's divergence with some studied EU countries in terms of the level of the banking sector development. Thus, the study corroborated the research hypothesis that the effective realization of the banking sector's potential has a significant relationship with the country's socio-economic development.

The novelty of this study lies in the methodological and conceptual approach to linking banking sector development between the economic growth of Ukraine, the vision of the potential of the banking sector in ensuring the country's sustainable development, which made it possible to take financial measures to realize the potential of the banking sector in ensuring Ukraine's economic growth.

\section{AUTHOR CONTRIBUTIONS}

Conceptualization: Nadiya Rushchyshyn, Taras Vasyltsiv.

Data curation: Olha Mulska, Nadiya Rushchyshyn.

Formal analysis: Olha Mulska, Nadiya Rushchyshyn.

Funding acquisition: Nadiya Rushchyshyn.

Investigation: Yuliia Nikolchuk.

Methodology: Olha Mulska.

Project administration: Yuliia Nikolchuk.

Resources: Mariia Rushchyshyn.

Software: Olha Mulska, Nadiya Rushchyshyn, Yuliia Nikolchuk, Mariia Rushchyshyn.

Supervision: Taras Vasyltsiv.

Validation: Nadiya Rushchyshyn, Taras Vasyltsiv.

Visualization: Mariia Rushchyshyn.

Writing - original draft: Nadiya Rushchyshyn.

Writing - review \& editing: Mariia Rushchyshyn, Taras Vasyltsiv.

\section{REFERENCES}

1. Aloqool, M., Okab, R., \& Basayreh, M. (2014). Financial Islamic banking development and economic growth: A case study of Jordan. International Journal of Economics and Finance, 6(3), 72-79. https://doi.org/10.5539/ijef. v6n3p72
2. Amandeep, K., \& Garima, M. (2019). Examining factors influencing Indian customers' intentions and adoption of internet banking: Extending TAM with electronic service quality. Innovative Marketing, 15(2), 4257. https://dx.doi.org/10.21511/ im.15(2).2019.04
3. Auster, S., \& Pavoni, N. (2018). Optimal Delegation and Limited Awareness, with an Application to Financial Intermediation. SSRN Electronic Journal. https://doi. org/10.2139/ssrn.3102831

4. Burianová, L., \& Paulík, J. (2014). Corporate Social Responsibility 
in Commercial Banking - A Case Study from the Czech Republic. Journal of Competitiveness, 6(1), 50-70. https://doi.org/10.7441/ joc.2014.01.04

5. Bushman, R.M., \& Williams, C.D. (2012). Accounting Discretion, Loan Loss Provisioning, and Discipline of Banks' RiskTaking. Journal of Accounting and Economics, 54, 1-18. https://doi. org/10.2139/ssrn.1521584

6. Caporale, M., Rault Leo, Sova, R., \& Sova, A. (2009). Financial Development and Economic Growth: Evidence from Ten New EU Members. Economic and financial working paper series, 3-37. West London: Brunel University.

7. Casta, J., Lejard Ch., \& PagetBlanc, E. The Implementation of the IFRS 9 in Banking Industry. EUFIN 2019: The 15th Workshop on European Financial Reporting. Aug 2019, Vienne, Austria. Retrieved from https://hal.archivesouvertes.fr/hal-02405140

8. Casu, B., \& Girardone, C. (2009). Testing the relationship between competition and efficiency in banking: A panel data analysis. Economics Letters, 105(1), 134137. https://doi.org/10.1016/j. econ-let.2009.06.018

9. Chanderjeet, Dr. (2017). Organizational development impact at banking industry. International Journal of Academic Research and Development, 2(6), 736739. https://doi.org/10.21474/ IJAR01/4968

10. Flamee, M., \& Windels, P. (2009). Restructuring financial sector supervision: Creating a level playing field. The Geneva Papers on Risk and Insurance. Issues and Practice, 34(1), 9-23. https://doi. org/10.1057/gpp.2008.36

11. Fonseca, A.R., \& Gonzalez, F. (2008). Cross-country determinants of bank income smoothing by managing loan-loss provisions. Journal of Banking and Finance, 32, 217-228. https://doi. org/10.1016/j.jbankfin.2007.02.012

12. FSB. (2013). Recovery and Resolution Planning for Systemically Important Financial Institutions:
Guidance on Identification of Critical Functions and Critical Shared Services. Retrieved from https:// www.fsb.org/2013/07/r_130716a/

13. Gabor, D., \& Brooks, S. (2017). The digital revolution in financial inclusion: International development in the fintech era. New Political Economy, 22(4), 423-436. https://doi.org/10.1080/13563467. 2017.1259298

14. Gebhardt, G., Reichardt, R., \& Wittenbrink, C. (2003). Accounting for Financial Instruments in the Banking Industry: Conclusions from a Simulation Model. CFS Working Paper Series 2003/21. Center for Financial Studies (CFS).

15. Hashim, N., Li, W., \& O’Hanlon, J. (2016). Expected-loss-based Accounting for Impairment of Financial Instruments: The FASB and IASB Proposals 2009-2016. Accounting in Europe, 13, 1-39. https://doi.org/10.1080/17449480. 2016.1210179

16. Ilyash, O., Yildirim, O., Doroshkevych, D., Smoliar, L., Vasyltsiv, T., \& Lupak, R. (2020). Evaluation of enterprise investment attractiveness under circumstances of economic development. Bulletin of Geography. Socioeconomic Series, 47, 95-113. http:// doi.org/10.2478/bog-2020-0006

17. Liang, H., \& Reichert, A. (2006). The relationship between economic growth and banking sector development. Banks and Bank Systems, 1(2), 19-35. https://doi.org/10.1051/matecconf/201710005032

18. Luo, Y. (2015). CEO power, ownership structure and pay performance in Chinese banking. Journal of Economics and Business, 82, 3-16. https://doi.org/10.1016/j. jeconbus.2015.04.003

19. Mantzari, E., Sigalas, C., \& Hines, T. (2017). Adoption of the International Financial Reporting Standards by Greek non-listed companies: The role of coercive and hegemonic pressures. Accounting Forum, 41(3), 185-205. https://doi. org/10.1016/j.accfor.2017.04.003

20. Maurice Ayuketang Nso. (2018). The role of e-banking as a market- ing tool. Innovative Marketing, 14, 56-65. https://doi.org/10.21511/ im.14(4).2018.05

21. Munteanu, I. (2012). Bank liquidity and its determinants in Romania. Procedia Economics and Finance, 3, 993-998. https://doi.org/10.1016/S22125671(12)00263-811

22. Naceur, S. B., Ben-Khedhiri, H., \& Casu, B. (2009). What drives efficiency of selected MENA banks? A meta-frontier analysis (IMF Working Paper No. WP/11/34). Retrieved from https://www.imf. org/external/pubs/ft/wp/2011/ wp1134.pdf

23. Novotny-Farkas, Z. (2016). The Interaction of the IFRS 9 Expected Loss Approach with Supervisory Rules and Implications for Financial Stability. Accounting in Europe, 13, 197-227. https://doi.org/10.108 0/17449480.2016.1210180

24. OECD. (2017). Business and Finance Outlook 2016. Retrieved from https://www.oecd.org/daf/ oecd-business-and-finance-outlook-2016-9789264257573-en.htm

25. Pushkala, N., Mahamayi, J., \& Venkatesh, K. A. (2017). Liquidity and off balance sheet items: A comparative study of public and private sector banks in India. SDMIMD Journal of Management, 8(1), 85-93. https://doi. org/10.18311/sdmimd/2017/15721

26. Rajesh, S. N., Raj Kunal Sen, \& Vinish Kathuria (2014). Does banking development matter for new firm creation in the informal sector? Evidence from India. Review of Development Finance, 4(1), 38-49. https://doi.org/10.1016/j. rdf.2014.03.003

27. Revelli, C., \& Viviani, J.-L. (2015). Financial performance of socially responsible investing (SRI): what have we learned? A meta-analysis. Business Ethics: A European Review, 24(2), 158-185. https://doi. org/10.1111/beer.12076

28. Ruthenberg, D., \& Landskroner, Y. (2008). Loan pricing under Basel II in an imperfectly competitive banking market. Journal of Banking \& Finance, 32(12), 2725-2733. https://doi.org/10.1016/j.jbankfin.2008.07.009 
29. Ryan, S. (2011). Financial Reporting for Financial Instruments. Foundation and Trends in Accounting, 6, 187-354. https://doi. org/10.1561/1400000021

30. Schaeck, K., \& Čihák, M. (2008). How does competition affect efficiency and soundness in banking? New empirical evidence (Working Paper Series No. 932). European Central Bank. Retrieved from https://www.ecb.europa.eu/pub/ pdf/scpwps/ecbwp932.pdf

31. Sivasubramaniam, S. (2018). Corporate Governance and Firm Performance: Empirical Evidence from Emerging Market. Asian Economic and Financial Review, 8, 1415-1421. https://doi.org/10.18488/journal. aefr.2018.812.1415.1421

32. Sobana, G. (2014). Study on Organizational Development in Banking Sectors in Kumbakonam Region. SSRG International Journal of Economics and Management Studies, 4, 1-3. https://doi.
org/10.14445/23939125/IJEMSV1I2P104

33. Storonyanska, I. (2015). Strategic priorities of regional financial policy modernization. Economic Annals-XXI, 1-2(1), 89-92. Retrieved from http://soskin.info/ userfiles/file/2015/1-2_1_2015/ Storonyanska.pdf

34. Vasyltsiv, T.G., \& Cherkasova, S.V. (2016). The influence of nonbanking institutional investor's activity on national financial services market development. Actual Problems of Economics, 176(2), 252-260.

35. Wahyudi, S., Nabella, R., \& Sari, K. (2021). Measuring the competition and banking efficiency level: a study at four commercial banks in Indonesia. Banks and Bank Systems, 16(1), 17-26. https://doi. org/10.21511/bbs.16(1).2021.02

36. Weber, O., Hoque, A., \& Islam, M. A. (2015). Incorporating environmental criteria into credit risk management in Bangladeshi banks. Journal of Sustainable
Finance and Investment, 5(1-2), 1-15. https://doi.org/10.1080/2043 0795.2015 .1008736

37. Yasynska, N., Syrmamiikh, I. \& Penez, O. (2021). Monitoring the financial security of the Ukrainian banking sector in the context of system-deterministic challenges. Banks and Bank Systems, 16(2), 12-26. https://doi.org/10.21511/ bbs.16(2).2021.02

38. Yuksel, S., Mukhtarov, S., Mammadov, E., \& Ozsan, M. (2018). Determinants of Profitability in the Banking Sector: an Analysis of Post-Soviet Countries. Economies, 6(41), 1-15. https://doi. org/10.3390/economies6030041

39. Zetzsche, D. A., Arner, D. W., Buckley, R. P., \& Weber, R. H. (2019). The future of data-driven finance and RegTech: Lessons from EU big bang II (EBI Working Paper Series, no. 35). Retrieved from http://www.fin-reg.uzh.ch/dam/ jcr:541d7562-6698-4143-8ad61676f8c30745/ssrn-id3359399.pdf 


\section{APPENDIX A.}

Table A1. Weighted coefficients of indicators of the banking sector development of some EU countries, Switzerland, and Ukraine, 2000-2019

Source: Calculations based on World Bank data.

\begin{tabular}{|c|c|c|c|c|c|c|c|c|c|c|c|c|}
\hline \multirow[b]{2}{*}{ Indicators } & \multicolumn{10}{|c|}{ Years } & \multicolumn{2}{|c|}{ Deviation } \\
\hline & 2000 & 2003 & 2006 & 2009 & 2012 & 2015 & 2016 & 2017 & 2018 & 2019 & $\begin{array}{l}2019 / \\
2000\end{array}$ & $\begin{array}{c}2019- \\
2000 \\
\end{array}$ \\
\hline \multicolumn{13}{|c|}{ Czech Republic } \\
\hline 1. The ratio of bank capital and assets, $\%$ & 0.8104 & 0.8188 & 0.8273 & 0.8572 & 0.8751 & 0.8887 & 0.8832 & 0.8663 & 0.8678 & 0.8742 & 1.0787 & 0.0638 \\
\hline 2. The ratio of liquid bank reserves and assets, $\%$ & 0.9097 & 0.9453 & 0.8978 & 0.8883 & 0.8827 & 0.9218 & 0.9411 & 0.9742 & 0.9712 & 0.9716 & 1.0680 & 0.0619 \\
\hline 3. The ratio of non-performing bank loans and total gross loans of banks, $\%$ & 0.8188 & 0.8335 & 0.8484 & 0.7879 & 0.7751 & 0.7708 & 0.7875 & 0.8073 & 0.8247 & 0.8398 & 1.0256 & 0.0210 \\
\hline 4. Number of branches of commercial banks, per 100,000 adults & 0.9560 & 0.9571 & 0.9557 & 0.9573 & 0.9592 & 0.9590 & 0.9566 & 0.9545 & 0.9545 & 0.9531 & 0.9970 & -0.0029 \\
\hline 5. Lending to the private sector by banks, $\%$ of GDP & 0.7866 & 0.7156 & 0.7556 & 0.7919 & 0.8043 & 0.8046 & 0.8087 & 0.8083 & 0.8094 & 0.8076 & 1.0267 & 0.0210 \\
\hline 6. Interest rate of banks on a loan, $\%$ & 0.7927 & 0.8146 & 0.8220 & 0.8138 & 0.8261 & 0.8549 & 0.8665 & 0.8773 & 0.8790 & 0.8739 & 1.1024 & 0.0812 \\
\hline 7. Spread of interest rates of banks, $\%$ & 0.8495 & 0.8273 & 0.8321 & 0.8249 & 0.8327 & 0.8491 & 0.8555 & 0.8625 & 0.8641 & 0.8630 & 1.0159 & 0.0135 \\
\hline 8. Credit information depth index, rank & 0.9540 & 0.9540 & 0.9540 & 0.9784 & 0.9784 & 0.9784 & 0.9784 & 0.9784 & 0.9784 & 0.9784 & 1.0256 & 0.0244 \\
\hline \multicolumn{13}{|c|}{ Poland } \\
\hline 1. The ratio of bank capital and assets, $\%$ & 0.9853 & 0.9800 & 0.9747 & 0.9773 & 0.9799 & 0.9826 & 0.9832 & 0.9851 & 0.9842 & 0.9834 & 0.9981 & -0.0019 \\
\hline 2. The ratio of liquid bank reserves and assets, $\%$ & 0.9413 & 0.9239 & 0.9254 & 0.9302 & 0.9423 & 0.9307 & 0.9277 & 0.9304 & 0.9277 & 0.9269 & 0.9847 & -0.0144 \\
\hline 3. The ratio of non-performing bank loans and total gross loans of banks, $\%$ & 0.9615 & 0.9492 & 0.9484 & 0.9524 & 0.9477 & 0.9521 & 0.9539 & 0.9545 & 0.9550 & 0.9554 & 0.9937 & -0.0061 \\
\hline 4. Number of branches of commercial banks, per 100,000 adults & 0.8837 & 0.8989 & 0.8821 & 0.9065 & 0.9108 & 0.8986 & 0.8980 & 0.8903 & 0.8922 & 0.8885 & 1.0054 & 0.0048 \\
\hline 5. Lending to the private sector by banks, $\%$ of GDP & 0.6889 & 0.6044 & 0.7112 & 0.7693 & 0.7792 & 0.7886 & 0.7910 & 0.7855 & 0.7857 & 0.7807 & 1.1333 & 0.0918 \\
\hline 6. Interest rate of banks on a loan, $\%$ & 0.6225 & 0.7476 & 0.7875 & 0.8053 & 0.8234 & 0.8419 & 0.8481 & 0.8545 & 0.8608 & 0.8672 & 1.3931 & 0.2447 \\
\hline 7. Spread of interest rates of banks, $\%$ & 0.7338 & 0.7994 & 0.8127 & 0.8306 & 0.8176 & 0.8048 & 0.8006 & 0.7964 & 0.7923 & 0.7881 & 1.0740 & 0.0543 \\
\hline 8. Credit information depth index, rank & 0.9739 & 0.9739 & 0.9739 & 1.0000 & 1.0000 & 1.0000 & 1.0000 & 1.0000 & 1.0000 & 1.0000 & 1.0268 & 0.0261 \\
\hline \multicolumn{13}{|c|}{ Romania } \\
\hline 1. The ratio of bank capital and assets, $\%$ & 0.9509 & 0.9569 & 0.9630 & 0.9431 & 0.9367 & 0.9386 & 0.9471 & 0.9468 & 0.9517 & 0.9604 & 1.0100 & 0.0095 \\
\hline 2. The ratio of liquid bank reserves and assets, $\%$ & 0.9051 & 0.9039 & 0.9248 & 0.8247 & 0.7902 & 0.7958 & 0.7887 & 0.7943 & 0.7623 & 0.7636 & 0.8437 & -0.1415 \\
\hline 3. The ratio of non-performing bank loans and total gross loans of banks, $\%$ & 0.9290 & 0.8564 & 0.8288 & 0.8743 & 0.8360 & 0.8495 & 0.8650 & 0.8840 & 0.8963 & 0.9056 & 0.9748 & -0.0234 \\
\hline 4. Number of branches of commercial banks, per 100,000 adults & 0.9476 & 0.9438 & 0.9311 & 0.9482 & 0.9401 & 0.9267 & 0.9245 & 0.9200 & 0.9162 & 0.9092 & 0.9595 & -0.0384 \\
\hline 5. Lending to the private sector by banks, $\%$ of GDP & 0.6807 & 0.7380 & 0.7931 & 0.8268 & 0.8288 & 0.8064 & 0.8005 & 0.7948 & 0.7921 & 0.7883 & 1.1581 & 0.1076 \\
\hline 6. Interest rate of banks on a loan, $\%$ & 0.5663 & 0.6375 & 0.7007 & 0.6777 & 0.7244 & 0.7858 & 0.8072 & 0.8105 & 0.7851 & 0.7788 & 1.3752 & 0.2125 \\
\hline 7. Spread of interest rates of banks, $\%$ & 0.6111 & 0.6486 & 0.6978 & 0.7641 & 0.7522 & 0.7743 & 0.7819 & 0.7796 & 0.7592 & 0.7621 & 1.2471 & 0.1510 \\
\hline 8. Credit information depth index, rank & 0.9582 & 0.9582 & 0.9582 & 0.9582 & 0.9804 & 0.9804 & 0.9804 & 0.9804 & 0.9804 & 0.9804 & 1.0232 & 0.0222 \\
\hline \multicolumn{13}{|c|}{ Hungary } \\
\hline 1. The ratio of bank capital and assets, $\%$ & 0.9499 & 0.9563 & 0.9627 & 0.9416 & 0.9347 & 0.9367 & 0.9458 & 0.9454 & 0.9506 & 0.9599 & 1.0105 & 0.0100 \\
\hline 2. The ratio of liquid bank reserves and assets, $\%$ & 0.7953 & 0.7289 & 0.7532 & 0.8000 & 0.8314 & 0.8503 & 0.7708 & 0.7484 & 0.7227 & 0.7455 & 0.9374 & -0.0498 \\
\hline
\end{tabular}


Years

Deviation

\begin{tabular}{|c|c|c|c|c|c|c|c|c|c|c|c|c|}
\hline \multirow[b]{2}{*}{ Indicators } & \multicolumn{10}{|c|}{ Years } & \multicolumn{2}{|c|}{ Deviation } \\
\hline & 2000 & 2003 & 2006 & 2009 & 2012 & 2015 & 2016 & 2017 & 2018 & 2019 & $\begin{array}{l}2019 / \\
2000\end{array}$ & $\begin{array}{c}2019- \\
2000\end{array}$ \\
\hline 3. The ratio of non-performing bank loans and total gross loans of banks, $\%$ & 0.7720 & 0.7648 & 0.7577 & 0.6681 & 0.6013 & 0.6324 & 0.6791 & 0.7439 & 0.8081 & 0.8732 & 1.1311 & 0.1012 \\
\hline 4. Number of branches of commercial banks, per 100,000 adults & 0.9078 & 0.9113 & 0.9160 & 0.9213 & 0.9157 & 0.9121 & 0.9104 & 0.9102 & 0.9083 & 0.9385 & 1.0338 & 0.0307 \\
\hline 5. Lending to the private sector by banks, $\%$ of GDP & 0.8425 & 0.8535 & 0.8754 & 0.8959 & 0.8809 & 0.8505 & 0.8464 & 0.8440 & 0.8438 & 0.8463 & 1.0045 & 0.0038 \\
\hline 6. Interest rate of banks on a loan, $\%$ & 0.7144 & 0.7454 & 0.7658 & 0.7293 & 0.7530 & 0.8990 & 0.9465 & 0.9989 & 1.0000 & 0.9695 & 1.3571 & 0.2551 \\
\hline 7. Spread of interest rates of banks, $\%$ & 0.8178 & 0.8597 & 0.8904 & 0.8402 & 0.8487 & 0.9105 & 0.9369 & 0.9530 & 0.9478 & 0.9195 & 1.1244 & 0.1017 \\
\hline 8. Credit information depth index, rank & 0.9248 & 0.9248 & 0.9248 & 0.9483 & 0.9483 & 0.9483 & 0.9483 & 0.9681 & 0.9681 & 0.9681 & 1.0468 & 0.0433 \\
\hline \multicolumn{13}{|c|}{ Ukraine } \\
\hline 1. The ratio of bank capital and assets, $\%$ & 0.9813 & 0.9864 & 0.9836 & 0.9879 & 0.9999 & 0.9463 & 0.9629 & 0.9796 & 0.9710 & 0.9905 & 1.0094 & 0.0092 \\
\hline 2. The ratio of liquid bank reserves and assets, $\%$ & 0.7148 & 0.6555 & 0.6454 & 0.5897 & 0.6007 & 0.6871 & 0.6839 & 0.6817 & 0.6771 & 0.7718 & 1.0797 & 0.0570 \\
\hline 3. The ratio of non-performing bank loans and total gross loans of banks, $\%$ & 0.5506 & 0.6070 & 0.5461 & 0.6646 & 0.6481 & 0.6041 & 0.5975 & 0.5528 & 0.5552 & 0.5618 & 1.0203 & 0.0112 \\
\hline 4. Number of branches of commercial banks, per 100,000 adults & 0.9098 & 0.9087 & 0.9108 & 0.9051 & 0.8722 & 0.8536 & 0.8499 & 0.8474 & 0.8460 & 0.8451 & 0.9289 & -0.0647 \\
\hline 5. Lending to the private sector by banks, $\%$ of GDP & 0.5582 & 0.6583 & 0.7440 & 0.8258 & 0.7743 & 0.7530 & 0.7228 & 0.6913 & 0.6750 & 0.6484 & 1.1616 & 0.0902 \\
\hline 6. Interest rate of banks on a loan, $\%$ & 0.5757 & 0.6616 & 0.6799 & 0.6450 & 0.6586 & 0.6403 & 0.6538 & 0.6713 & 0.6551 & 0.6505 & 1.1299 & 0.0748 \\
\hline 7. Spread of interest rates of banks, \% & 0.5451 & 0.6472 & 0.6917 & 0.7003 & 0.7357 & 0.6731 & 0.6892 & 0.6976 & 0.6981 & 0.7035 & 1.2906 & 0.1584 \\
\hline 8. Credit information depth index, rank & 0.9968 & 0.9968 & 0.9968 & 0.9968 & 0.9968 & 0.9985 & 0.9985 & 0.9985 & 0.9985 & 0.9985 & 1.0017 & 0.0017 \\
\hline \multicolumn{13}{|c|}{ Switzerland } \\
\hline 1. The ratio of bank capital and assets, $\%$ & 0.8874 & 0.8735 & 0.8595 & 0.8746 & 0.8736 & 0.9072 & 0.9043 & 0.9189 & 0.9231 & 0.9274 & 1.0451 & 0.0400 \\
\hline 2. The ratio of liquid bank reserves and assets, $\%$ & 0.8999 & 0.9546 & 0.8818 & 0.8675 & 0.8591 & 0.9184 & 0.9481 & 1.0000 & 0.9952 & 0.9959 & 1.1067 & 0.0960 \\
\hline 3. The ratio of non-performing bank loans and total gross loans of banks, $\%$ & 0.9238 & 0.9117 & 0.9436 & 0.9224 & 0.9692 & 0.9774 & 0.9788 & 1.0000 & 0.9950 & 0.9986 & 1.0810 & 0.0748 \\
\hline 4. Number of branches of commercial banks, per 100,000 adults & 1.0000 & 0.9909 & 0.9833 & 0.9751 & 0.9640 & 0.9497 & 0.9433 & 0.9377 & 0.9330 & 0.9287 & 0.9287 & -0.0713 \\
\hline 5. Lending to the private sector by banks, $\%$ of GDP & 0.9639 & 0.9628 & 0.9721 & 0.9767 & 0.9840 & 0.9872 & 0.9910 & 0.9940 & 0.9970 & 1.0000 & 1.0375 & 0.0361 \\
\hline 6. Interest rate of banks on the loan, $\%$ & 0.8745 & 0.9047 & 0.9134 & 0.9245 & 0.9272 & 0.9275 & 0.9290 & 0.9299 & 0.9299 & 0.9296 & 1.0630 & 0.0551 \\
\hline 7. Spread of interest rates of banks, $\%$ & 0.9863 & 0.9368 & 0.9728 & 0.9453 & 0.9455 & 0.9420 & 0.9415 & 0.9405 & 0.9397 & 0.9389 & 0.9519 & -0.0474 \\
\hline 8. Credit information depth index, rank & 1.0000 & 1.0000 & 1.0000 & 1.0000 & 0.9825 & 0.9825 & 0.9825 & 0.9825 & 0.9825 & 0.9825 & 0.9825 & -0.0175 \\
\hline
\end{tabular}

